\title{
THE APPLICATION OF THE CONCEPT OF ECO GREEN- TOURISM IN DEVELOPING THE TOURIST VILLAGE THROUGH THE LOW IMPACT DEVELOPMENT
}

\author{
Wiwik Setyaningsih*, Tri Yuni Iswati*, Sri Yuliani* \\ *) Department of Architecture, Sebelas Maret University, Indonesia \\ e-mail: wiwikhermono@yahoo.co.id
}

\begin{abstract}
The concept of green eco-tourism is a concept of regional development for environmentally sustainable tourism activities. Tourism activities have a significant effect on the development and improvement of the economic, social, cultural sectors and the quality of the surrounding environment which subsequently causes the global issue of World Tourism Organization (WTO) to emerge. It is then relevant to apply the concept of eco-green tourism in developing the strategic areas intended for tourism in line with the program of the government of Surakarta city which aims at developing the city within the concept of eco-culture city.

Some tourist villages (kampung wisata) with local wisdom potentials as the historical areas in Surakarta city are still not handled optimally. This trend can be seen in some of areas which have begun to lose their original characteristics and have even changed function. This phenomenon will slowly and certainly erode the local wisdoms of the historical villages which will eventually cause the unique characteristics as the local potentials of the city to disappear. Therefore, one of the right and integrated actions to handle such a problem is the research model of development of the tourist villages through LID (Low Impact Development) by having the concept of eco-green tourism.

The objective of this research is to formulate the model of development of the tourist villages through LID (Low Impact Development) in bringing eco-green tourism into reality. This formulation is based on descriptive explorative method. This research was conducted in the historical area of Kauman tourist village which still has the authenticity of potentials of the value of characteristics of high local wisdoms which are still in existence and development.

The results of this research are the model formulation for policy in developing Kauman tourist village. Such a policy model is expected to be able to become the pilot project of the development of the tourist villages not only in Surakarta city but also in other tourist cities in Indonesia in general through the implementation of eco-green tourism on the basis of the concept of green architecture which will not only conserve the tourism, cultural, and environmental assets, but also empower the prevailing local wisdoms.
\end{abstract}

Keywords: eco-green tourism, tourist village, low impact development 
Setyaningsih, Iswati, Yuliani: THE APPLICATION OF THE CONCEPT OF ECO GREEN-TOURISM IN DEVELOPING THE TOURIST VILLAGE THROUGH THE LOW IMPACT DEVELOPMENT

\begin{abstract}
ABSTRAK
Konsep green eco-tourism adalah konsep pembangunan daerah untuk kegiatan wisata lingkungan yang berkelanjutan. Kegiatan pariwisata memiliki dampak yang signifikan pada pengembangan dan peningkatan sektor ekonomi, sosial, budaya dan kualitas lingkungan sekitar yang kemudian menyebabkan isu global World Tourism Organization (WTO) muncul. Sehingga relevan untuk menerapkan konsep pariwisata eco-green dalam mengembangkan daerah strategis yang ditujukan untuk pariwisata sejalan dengan program Pemerintah Kota Surakarta yang bertujuan untuk mengembangkan kota dalam konsep kota eco-budaya.

Beberapa kampung wisata dengan potensi kearifan lokal sebagai daerah bersejarah di kota Surakarta masih belum ditangani secara optimal. Kecenderungan ini bisa dilihat di beberapa daerah yang telah mulai kehilangan karakteristik asli mereka dan bahkan telah berubah fungsi. Fenomena ini perlahan dan pasti akan mengikis kearifan lokal dari kampung-kampung bersejarah yang pada akhirnya akan menyebabkan karakteristik unik sebagai potensi lokal kota menghilang. Oleh karena itu, salah satu tindakan yang tepat dan terpadu untuk menangani masalah tersebut adalah model penelitian pengembangan kampung wisata melalui LID (Low Impact Development/Pembangunan Berdampak Rendah) dengan memiliki konsep pariwisata eco-green.

Tujuan dari penelitian ini adalah untuk merumuskan model pengembangan kampung wisata melalui LID (Pembangunan Berdampak Rendah) untuk mewujudkan pariwisata eco-green menjadi kenyataan. Formulasi ini didasarkan pada metode deskriptif eksploratif. Penelitian ini dilakukan di wilayah bersejarah kampung wisata Kauman yang masih memiliki keaslian potensi nilai karakteristik kearifan lokal yang tinggi yang masih ada dan dalam pengembangan.

Hasil penelitian ini adalah perumusan model kebijakan dalam mengembangkan kampung wisata Kauman. Model kebijakan tersebut diharapkan dapat menjadi proyek percontohan pengembangan kampung wisata tidak hanya di kota Surakarta, tetapi juga di kota-kota wisata lainnya di Indonesia secara umum melalui penerapan pariwisata eco-green atas dasar konsep arsitektur hijau yang tidak hanya akan melestarikan asset pariwisata, budaya, dan lingkungan, tetapi juga memberdayakan kearifan lokal yang berlaku.
\end{abstract}

Kata kunci: pariwisata eco-green, kampung wisata, pengembangan berdampak rendah

\title{
INTRODUCTION
}

WTO (World Tourism Organization) is a world organization which takes tourism issues into account in increasing the economic, social and cultural sectors and environmental dimension. The tourism of Indonesia has an opportunity to empower the existence of tourist village with the domestication of local wisdom as a valuable asset in moving toward eco-green tourism. The comprehensive development of tourist village is conducted by integrating various stakeholders influencing the increase in 
local wisdom potentials. At present people still tend not to take into account and comprehend the existence of local wisdom potentials of the tourist villages which can be put in a package as the high-value asset of green tourism.

This research used descriptive explorative method in which the study on the local wisdom potentials in the public space arrangement of the city, the mapping of the characteristics of social, cultural, and economic potentials, and the behavioral setting with eco-green tourism approach. Up to the present there has not been any research which recommends a model formulation on the concept to develop tourist village on the basis of low impact development as the realization of eco-green tourism. Such a condition causes any policy of the government and concern of the public on the local wisdom potentials not to emerge yet in the realization of eco-green tourism within the historical area of tourist village. Therefore, the objective of this research is to obtain the formulation on the development model for the tourist villages as the realization of eco-green tourism through the exploration of the potentials of the characteristics of local wisdom domestication (physical and non-physical).

This is a research study urgent to conduct due to its variable of green tourism. Thus, the potentials of the local wisdom domestication of the area can be conserved, developed, and packed to be an eco-green tourism asset in the development of a proper, unique, and original tourist village. The Unit of Study on Architectural Heritage (USAH) of the Faculty of Engineering of Sebelas Maret University is obliged to take action and conduct research as a realization of concern. So, the research team in USAH raises the theme for research in accordance with the Research Master plan and Roadmap of Sebelas Maret University in the years of 2009-2020 on the making of conservation, domestication, and preservation. The results of the research as the guideline for integrated and comprehensive policy as well as the new findings to enrich the treasure of knowledge and science will be recommended, socialized, and promoted to the stakeholders to be able to be brought into reality and implemented in an integrated way.

\section{THEORY/ RESEARCH METHODS}

\section{Development of Urban Tourist Village}

The elaboration of the vision of tourism development in developing tourist destination is aimed at developing the active role of the people. The people have strategic roles and positions as the subjects and recipients of benefits of development, and the stakeholders in the tourism development (Stupa, 2010). Meanwhile, Kostof (1991) puts forward that village is a form of urban settlement located in the important part of the function of the city, inclusive of the area of Central Business District (CBD), center of government, shopping center, and social center. As for urban village, it is a settlement area which has already aimed at being urbanized in which several types of urban service have been available and the characteristic features of a city have already been had.

Urban village is a dynamic and important economic system in such a way that it needs to be integrated with a comprehensive city system, physically, socially, and 
economically. Thus, urban village can be seen as one living, growing, and developing organism and it becomes the center and event for various productive activities of its inhabitants or home-based enterprises (Setiawan, 2010). In addition, urban village can also support urban economic activities. The diversity, uniqueness, and persistence of the inhabitants of the urban village will determine the uniqueness and even the soul of the cities in Indonesia (Sullivan, 1980).

Suhartanti (2000) states that the characteristic features of the life of Indonesian people is unique indicated by a kind of life which regards other people more or less like the members of one's own family, commensurate level of living, religious harmony, and motivation for mutual cooperation and shared expediency. Therefore, such characteristics are expected to support the growth and development of tourist villages in Surakarta. There are three principal components as the basic foothold for the growth and development of urban village which include: access, resources, and motivation. The different levels of ability of each component will contribute to the formation or phenomenon which is different as well to the urban village.

Lane (1994) contends that tourist village is a series of tourism activities taking place in the area of a village. The idea of tourist village comes from the demand of tourists to visit some villages regarded to have special uniqueness. The atmosphere, life, and tradition of the people living in the local village are the main assets in the development of tourist village (Bramwell, 1994). The local wisdom potentials in the village are assets of eco-green tourism in the tourism sector which have to be preserved and packed as a unique and original tourism products with high value (Sharpley, 1993). Therefore, the active role support of the people highly determines the sustainability within the tourism village destination (Ganon, Agness, 1992).

Tourist village is theoretically defined as an area or village with the potentials of high uniqueness value and local wisdoms as unique tourist attractions either in the physical characteristics of natural environment or the social and cultural life of the local people managed, packed, and presented attractively with the development of the facilities to support tourism in a harmonious environment system and good, integrated, and well-planned management so that the village is ready to receive the visit of both domestic and foreign tourists (Sharpley, 1997; Bromley, 1994).

A conclusion is drawn out of the theories mentioned above that tourist village is a form of tourism with the concentration on the local wisdom potentials supported by other unique potentials which have become the unique characteristics of a village (Figure 1). The object and attraction of the life of a village with the unique characteristics of the local people (both physical and non-physical) which have an opportunity to become the commodity assets for visitors or tourists to enjoy as well as everything generated from the activities of the village will bring benefits to the local people. 


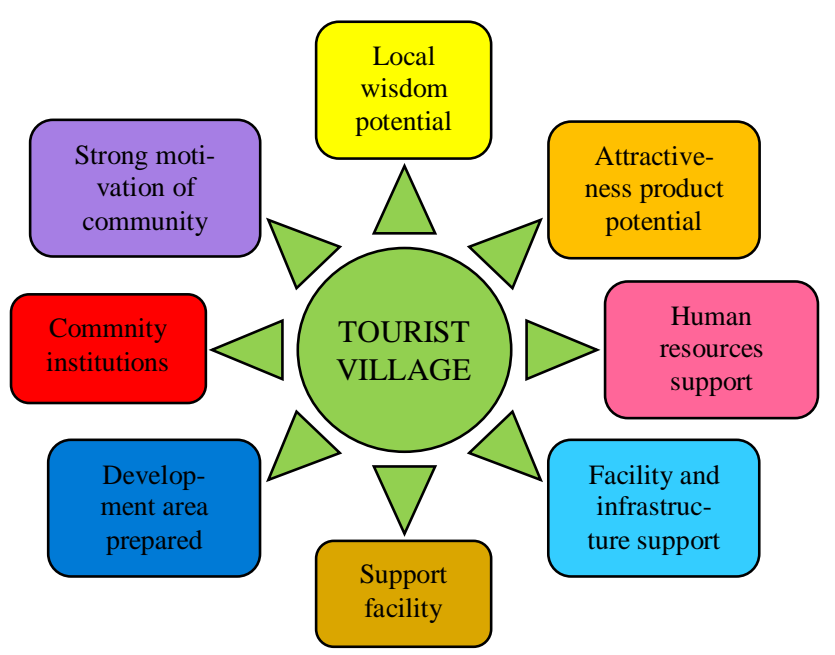

Figure 1. Eight Components to Establish Tourist Village Source: Setyaningsih, 2011 reanalyzed in 2013

\section{Low Impact Development (LID)}

The basic concept of LID is the sustainable management of drainage with environmentally friendly public space arrangement system (able to filter pollution, control the volume of rainwater, and maintain the base flow which flows to the body of water). Meanwhile, sustainability is the utilization of natural, human, artificial, and social cultural resources with wisdom and under control to achieve high level of economic security and bring the ecological security into reality in all aspects of their life (Pirages, 1996).

Sustainable development essentially aims at improving the quality of life of human beings in all aspects, including religious, physical, spiritual, and cultural aspects without wasting the available natural resources. Furthermore, there are 9 (nine) principles of adaptation in sustainable development in City of Gold Coast, namely: respect for and maintenance of life community, improvement of the quality of life of human beings, preservation of the vitality and diversity of the earth, prevention from the squander of non-renewable natural resources, efforts to avoid doing any act which exceeds the supporting capacity of the eart, change of attitude, lifestyle, and behavior, support for the creativity of the people to take care of one's own environment, provision of comprehensive to integrate the effort of development and that of preservation, and creation of global cooperation.

\section{Eco-green Tourism}

The term 'eco-green tourism' emerges in a WTO meeting in Bali which is described as friendly and everlasting tourism development without the accompaniment of negative impacts against the environment (physical and non-physical). The success of tourism development based on eco-green tourism is highly determined by the quality of the natural and cultural environment as well as the behavior of the people. Tour- 
ism development has to take the harmony among the need of tourists, tourist destination, and local people as the host into account all the time (Nuryanti, 2010).

Thus, the development of tourist village based on eco-green tourism has to take the environment into by growing the awareness of the tourists to the characteristics of local wisdoms of the area. Such development of tourist village has to fulfill some criteria as follows: a) the existence of tourist village; b) the location has to possess the potentials of attraction of unique local wisdom; c) there is high motivation of the local people; d) there is enthusiasm of community development; and e) there is a sustainable system of partnership collaboration among the government, the private sector, and the local people.

\section{Research Methods}

This research was conducted by using descriptive explorative method which is an integration of the study on the local wisdom potentials in the urban space arrangement and the mapping of the characteristics of social economic and cultural potentials as well as the behavioral setting with the eco-green tourism approach.

This research was conducted in the historical area of Kauman tourist village of Surakarta on the basis of the dominant factor of potentials of domestication of local wisdoms of historical values related to the existence of Surakarta Palace as the symbol for the center of culture which still exists. The samples of this research, including the key informants, were taken by using purposive sampling technique and snowball sampling technique. The data of this research were gathered through participatory observation (SWOT - Strength, Weakness, Opportunity, and Threat analysis on the physical mapping of the characteristics of the area related to the potentials of domestication of local wisdoms), in-depth interview (the mapping of social economic and cultural characteristics by using survey through interview), questionnaire, documentary study, map reference, Focus Group Discussion, and Participatory Rural Appraisal (PRA) to gather the needs and aspiration of the people.

The data were then analyzed by using SWOT analysis on the area, descriptive statistic analysis technique, and interactive analysis technique as well as the behavioral setting which is related to the eco-green tourism approach (Figure 2). 


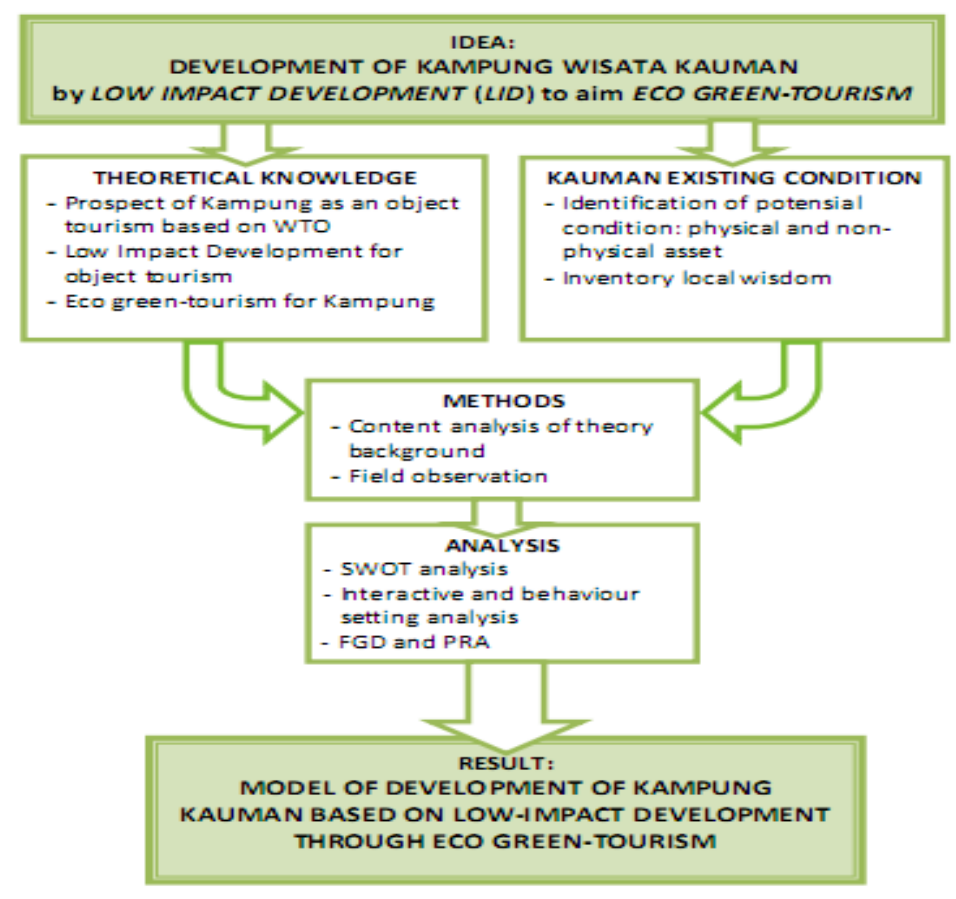

Figure 2. Research Framework Diagram Sources: Setyaningsih, 2013

\section{RESULTS AND DISCUSSION}

\section{Development of Tourist Village through Low Impact Development (LID)}

The change in space arrangement from a historical area to a tourist village in Kauman village will cause the quality of the environment to degrade due to the increase in pollution and waste. This is related to the problems in planning, building, and managing the drainage system of this area which has to refer to the techniques in Low Impact Development (LID). The implementation of LID in the space arrangement of Kauman village can set off from the implementation strategies as follows:

1. Selection of plain materials with soft structure

The implementation of this technique in LID is done by using materials with soft structure, such as concrete, stone, local plants, soils, and gravels since such materials can get fused into the condition of the surrounding area more easily and give more natural view than the conventional technique. The natural characteristics will probably raise acceptance and willingness to use and maintain this system as well.

Soft structure can be applied in the arrangement of circulation line within the area of Kauman village by taking into account the characteristics of the roads specified typically in accordance with the local wisdom. Based on the on-field data the roads in Kauman village are divided into two classes, namely: 
a. Five roads of main environment/tertiary road (Figure 3), which consist of:

- Kalimasada road, built from asphalt, 3.5 meters in width, two-way circulation

- KH Hasyim Asyari road, built from asphalt, 5 meter in width, one-way circulation

- Wijaya Kusuma road, built from asphalt, 4 meters in width, two-way circulation

- Trisula road, built from asphalt, 4 meters in width, two-way circulation

- Cakra road, built from concrete, 2 meters in width, two-way circulation
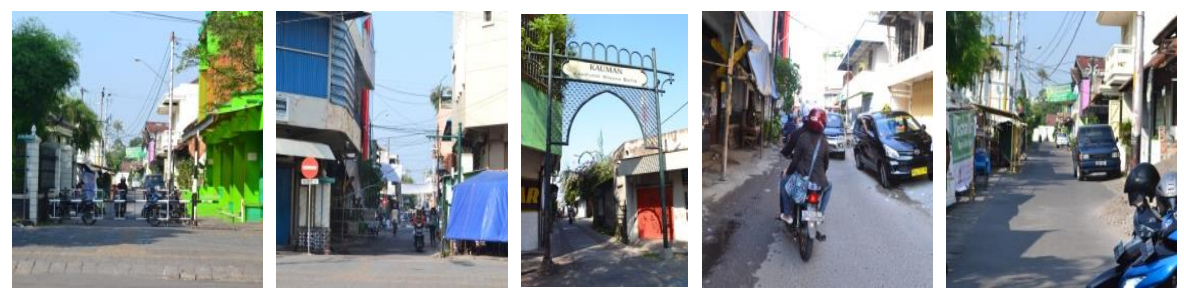

Figure 3. Condition of Five Main Roads in Kauman, Surakarta Source: Setyaningsih, 2013

b. The names of the roads in Kauman were given by the kings as the toponym of some heirlooms owned by Kasunanan Palace which become the symbol for glory and greatness and are regarded to have magical/sacred power. Such toponyms are as follows:

- Kalimasada road (the name of an amulet at the time of King Pakubuwono V)

- Trisula road (the name of an amulet at the time of Kings Pakubuwono VI through VII)

- Cakra road (the name of an amulet at the time of King Pakubuwono VIII)

- Wijaya Kusuma road (the name of an amulet found by Ketib Trayem IV from Nusakambangan Isles at the time of King Pakubuwono (Figure 4 and 5).

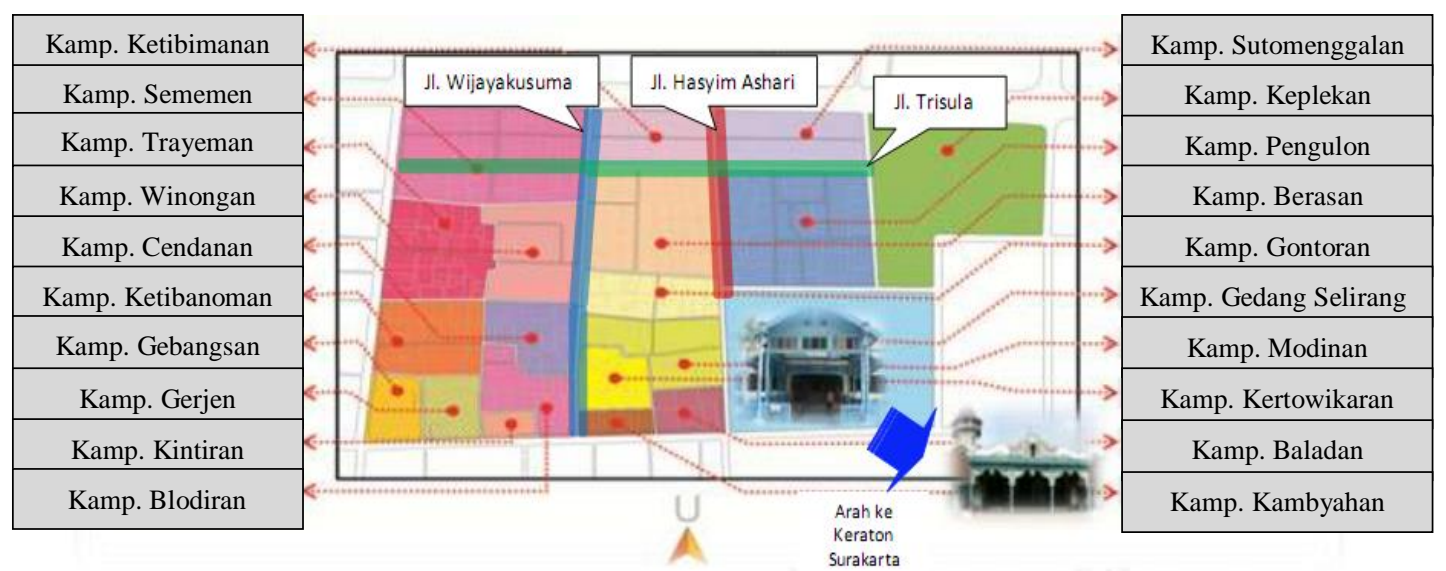

Figure 4. Main Streets of Kauman Tourism Village, Surakarta Source: Setyaningsih, 2013 


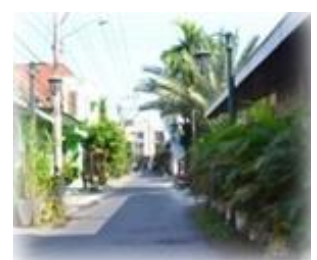

J1. Hasyim Asyari

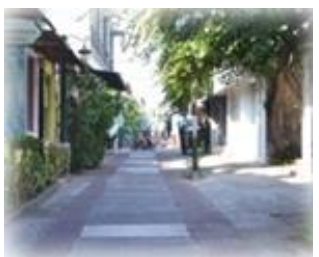

Jl. Trisula

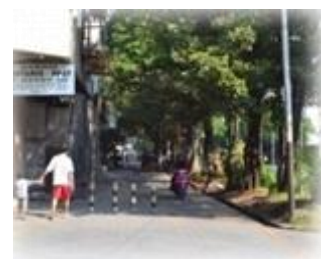

J1. Slamet Riyadi

Figure 5. The Condition of Main Streets of Kauman Tourism Village, Surakarta Source: Setyaningsih, 2013

LID is conducted by selecting and making LID units in accordance with the local need as follows:

1. Bioretention

It is an area of soil heap under the surface of plants with the characteristic of ability to release water and a drainage which pushes infiltrated flow as the water filter and prevents any addition of breadth and height. The method used is a combination of filtration with physical process and biological process.

2. Infiltration Well

It is a small pits refilled with aggregate, usually gravel or stone, which functions as infiltration system to control the flow of surface from the roof of the building and to make catchment of the inflow which takes the form of direct surface flow. Infiltration well provides the main treatment with the same process as the infiltration of ground water in which there is binding, filtering, and decomposing bacteria.

3. Vegetation Filter Land

Vegetation filter land is usually adjacent to vegetation area filled with grass.

4. Buffer Vegetation

It is buffer vegetation planted with plants, either those that grow on their own or those that is planted on purpose, around the sensitive area. Vegetation helps to hold sediment carried by the rainwater.

5. Grass Canal

It is contained in a conventional simple drainage canal with grass canal which mainly functions to helps the rain water get through and away from the road. The urban planner can plan dry canal which provides both quantity and quality by facilitating the infiltration of rainwater flow.

6. Rainwater Tub

It is a method to reserve rainwater with easy, cheap, and effective maintenance and suitability to be used in settlement area. Rainwater tub works by resisting the initial volume of rainwater flow whereas the run-off pipe operates as the water run-off after the rainwater flow exceeds the capacity. The tub has to be designed in such a way that it is easily transferable and safe for children. As well, the tub has to have mosquito filter fitted in the area surrounding the inlet hole.

7. Infiltration Trench

It is a kind of trench refilled with stone to form a tub under the surface (Figure 6). The rainwater flow is deflected into the trench and reserved until the water can be infiltrated into the soil, which usually takes several days. It has to be taken into 
account to prevent the trench from getting plugged (Figure 7). Therefore, the incoming water has to be processed first through grass canal or vegetation filter land.

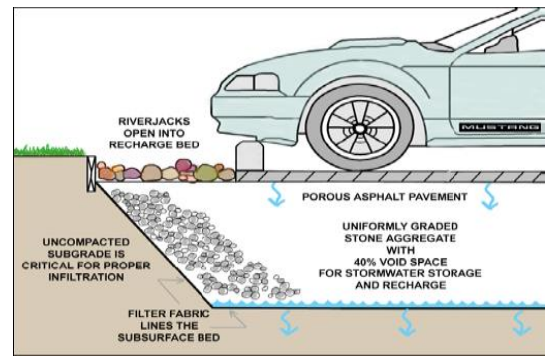

Figure 6. Permeable Paving

Source: Analysis of Hermono, 2010

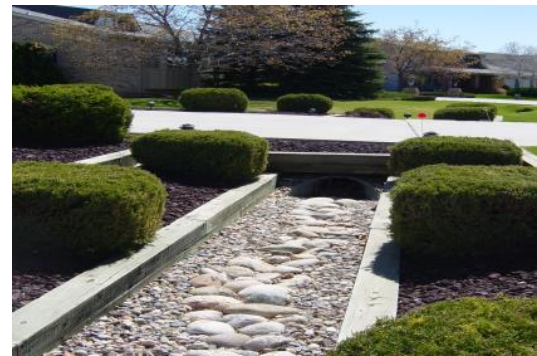

Figure 7. Infiltration Trench Source: Analysis of Hermono, 2010

The methods which can be used to minimize the flow of water cycle dumped are as follows (they can also be used in combination):

1. Building narrower/smaller road (reducing waterproof area)

2. Maximizing plant conservation

3. Minimizing nuisance

4. Building open drainage canal

5. Keeping the soil with high infiltration

6. Placing the flow of water cycle on the land with high infiltration

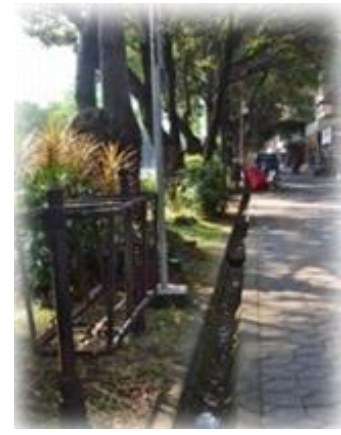

a. Availability of sanitary sewer on the side of the road

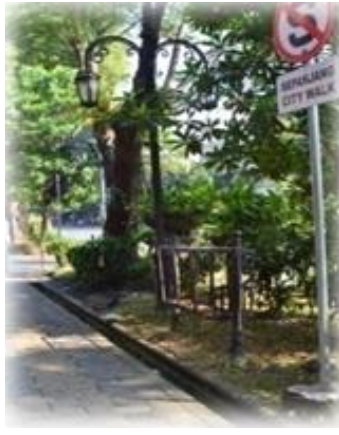

b. Street furniture as a decorative element applied to lampposts and bins

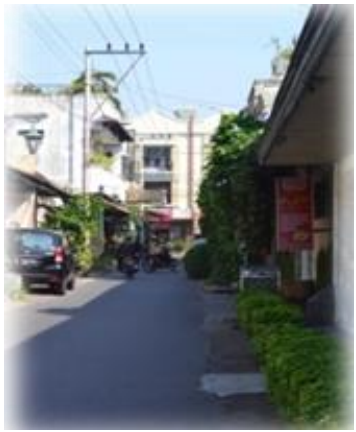

c. Outer side of the road which is used as a catchment area and improve air quality

Figure 8. Effort of Technical Design in Arranging Kauman Area Toward LID Source. Setyaningsih, 2013

The following steps in the management system of LID are to keep the concentration time (Tc) like the predevelopment time. The techniques usually used to keep the concentration time are as follows:

1. Keeping the length of flow line 
2. Increasing the surface roughness value (such as providing area for plants, using vegetation canal)

3. Resisting the water flow (by using such as open canal and bioretention)

4. Minimizing nuisance (such as by minimizing compaction and change in the available vegetation)

5. Making as little tilt as possible in the development area

6. Eliminating waterproof area

7. Connecting the water escape area and the vegetation area.

The drainage through closed pipe in LID would better be avoided (Figure 9). Open canal has to be designed by following a procedure as follows:

1. Raising the surface roughness to retard speed

2. Creating a condition of shallow water flow

3. Using network system in wide and flat canal to avoid fast canal movement

4. Raising canal track

5. Reducing the tilt of the canal to reduce speed (minimum slope of 20\%)

6. The canal has to pass through water escape ground in order to increase the absorption to reduce surface flow.

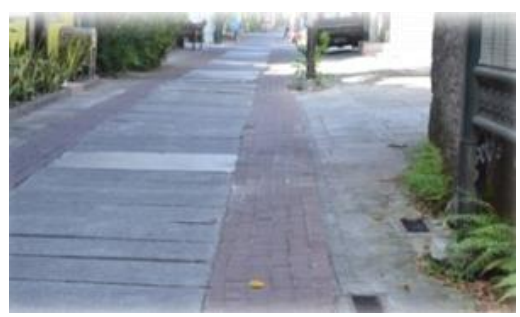

a. Circulation pathways in the Tourism Village Kauman using cast concrete with installation of porous so that water can get into the drainage channel in the middle, while the edge of the road there is infiltration area for environmental sustainability.

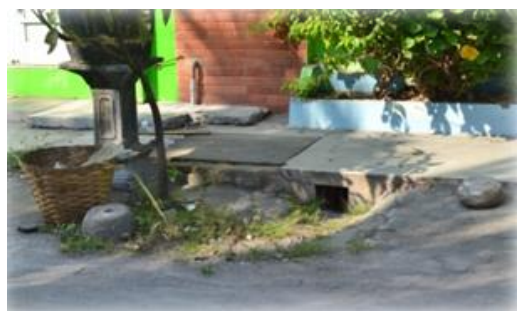

c. Provision of bins to reduce waste buildup burden on drainage.

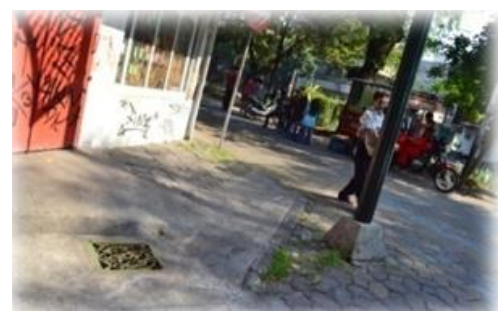

b. On type of drainage that flank the road, mounted control boxes to check and periodic maintenance of drainage channels.

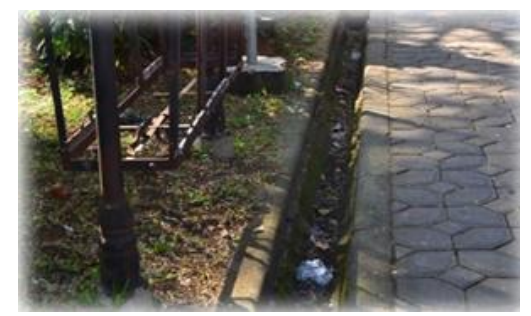

d. Drainage system with open surfaces to minimize runoff coefficient.

Figure 9. Drainage in The Area of Kauman village Source: Setyaningsih, 2013 


\section{Bringing Planning on Multifunctional Area into Reality}

LID offers an alternative of innovation in the approach of urban management of rainwater flow integrated with the planning on settlement area where the surface flow can be managed in small scale dan controlled in each source of pollution. Every city park or any other infrastructure (roof, street, parking lot, and green belt) can be designed to become multifunctional by having an environmentally sound retention pond by utilizing it as the detention, retention, and filtration of water and it can be used to accomodate the water flow.

Meanwhile, garden city concept and urban linkage system are needed in the management system in the following time. This system defines the area structure and its space clearly through the arrangement approach of urban landscape design on the basis of the concepts of garden city, greenbelt structure, and green in the area spaces/intersections/junctions passed by greenbelt or called greenbelt area in an integrated unit of landscape design for public park (Figure 10) with amenity as an effort to preserve environment sustainably.

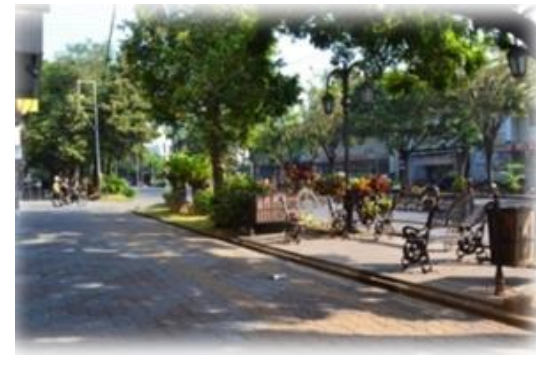

a. Public park placed on the outskirts of the village area Kauman a unique appeal to the entrance to the village, the landscape can be optimized by street furniture and shade plants.

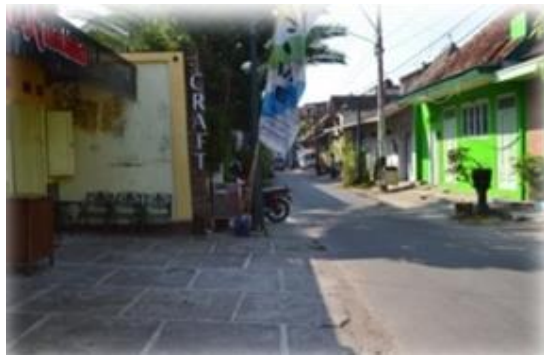

b. Public areas in the form of bags in the parking lot in the village Kauman circulation path. This bag can be optimized park with grass block pavement material so water can seep back into the ground.

Figure 10. Public Area of Kauman Village

Source: Setyaningsih, 2013

\section{Implementation of Eco-green Tourism in Arranging Kauman Tourist Village}

The concept of green tourism is aimed at keeping harmony among its elements, such as the need of tourism development, the continuity of environmental, social, and cultural functions, the quality of tourism products, human resource professionalism, and tourist satisfaction. The balance of the various elements has to be kept to prevent conflict between one element and another one. This is a concept of insight of sustainability of the elements as the maker and manager of tourism area in the future. Green tourism is done by making efforts in the change of culture and attitude in arranging the environment, behavior pattern, and lifestyle to support the sustainabil- 
ity of the tourist area as well as to form new attitude in the interaction between people and tourist area (Fundamentals of Green Tourism, 2010).

Green tourism as a complex and multifaceted activity includes environment as well as tourism to accommodate conservation education and recreation which grows rapidly by showing the authenticity of behavior of the local people and variety of uniqueness owned in such a way that communication can be built through the activities of interpretation and appreciation toward the local wisdom potentials.

The development of eco-green tourism principally emphasizes the wise utilization of natural and cultural resources by prioritizing the sustainability of existence and local wisdom and minimizing the negative impact of tourism against the environment. This concept should be comprehended for the agreement of all related parties in such a way that there will not be any contradiction among various interests in the application of eco-green tourism (Jatmiko, et all. 2011). Such an agenda brings benefit as the follow-up of green tourism to give direction to apply the sustainable development of tourist village which pays attention to the environmental needs and local people.

The same thing is put forward in the idea that the development of eco-green tourism has to pay more attention to the environment by growing the awareness of the tourists of the characters of local wisdom of a region. This is a process which involves various related parties to emphasize more on the utilization of the potentials and resources of local wisdom at hand for the importance of the wider community. Bringing eco-green tourism into reality with the sustainability from the past to the future generation and the right, creative, and sustainable ways of development without leaving the local image and characters behind eventually becomes our shared duty which has to be followed up immediately.

It is concluded out of the description above that the growth and development of tourist village toward eco-green tourism have to fulfill some criteria, such as the existence of tourist village, the potentials of attraction of unique local wisdom owned by the area/location, and the strong motivation of the local people to be creative in developing eco-green tourism by minimizing the negative impact toward green tourism as well as the enthusiasm of those involved in community development and sustainable partnership collaboration system among the government, the private sector, and the local people as the motor. Setyaningsih (2013) found that the community needs to turn its attention to the loss of character of the buildings in Kauman, if the Kauman area is further developed considering only economic activities and not conservational issues. In the meantime, local communities in Kauman have not yet understood and realized why it is important to maintain local identity, and that unique value is an important asset.

The development of the area of tourist village toward the planning on ecoculture city has to take into account the environmental handling, namely: keeping, protecting, and preserving the existence and condition of the nature and environment. Such a handling consists of the concepts as follows:

1. First, recycling. It means the utilization of technology, behavior of the people, and planning which enable to reprocess the waste products into the materials which can be reused without any negative impact against the environment. 
2. Second, sustainability. It means sustainable development with long-term vision and mission; and

3. Third, balance between artificial and natural environments, such as greenbelt, park, city forest to provide shady areas, $\mathrm{O}_{2}$ (oxygen), anti-pollutant to absorb $\mathrm{CO}_{2}$ (carbon dioxide) and plumbum content of the air as well as aesthetic elements and water conservation.

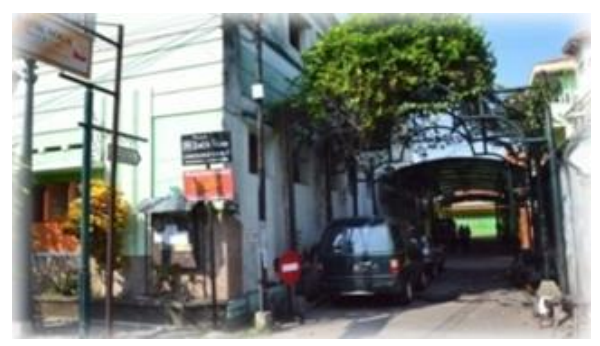

a. Village lane in shade circulation decoratively presented combined with green elements.

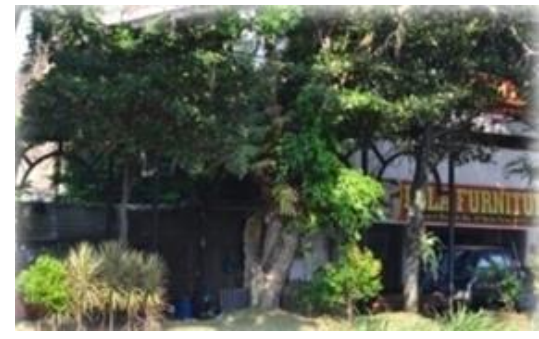

b. Space divider village using green elements as district cooling, green belt and paired with a decorative street furniture.

Figure 11. Effort of Design and Technique of The Arrangement of Kauman Area Toward Eco-Green Tourism Source: Setyaningsih, 2013

The implementation of design of eco-green tourism in Kauman village in more integrated way can be specified as follows:

Table 1. Implementation of Eco Green-Tourism-Based Model Design at Kauman Village

\begin{tabular}{|c|c|c|c|}
\hline No & Component & Strategy & Implementation \\
\hline 1. & $\begin{array}{l}\text { Access to the } \\
\text { village }\end{array}$ & $\begin{array}{l}\text { Strengthening the façade of the village } \\
\text { with local identity, entrance through a } \\
\text { uniquely shaped gate, and free and } \\
\text { spacious and communicative direction } \\
\text { of the entrance. }\end{array}$ & \\
\hline 2. & $\begin{array}{l}\text { Circulation } \\
\text { path }\end{array}$ & $\begin{array}{l}\text { Facilitating a circulation space within } \\
\text { the area of the village through provid- } \\
\text { ing safe and comfortable vehicle and } \\
\text { pedestrian tracks, parking space, and } \\
\text { freeway track. }\end{array}$ & \\
\hline 3. & Drainage & $\begin{array}{l}\text { Building environmentally friendly } \\
\text { canal for waste water by improvising } \\
\text { the green elements (green drainage) } \\
\text { through building drainage canal for } \\
\text { smooth-going water flow and catch- } \\
\text { ment area which has dual function as } \\
\text { village park as well. }\end{array}$ & \\
\hline
\end{tabular}


Table 1. Continue

\begin{tabular}{ccll}
\hline No & Component & \multicolumn{1}{c}{ Strategy } & Implementation \\
\hline 4. & Aesthetic & Providing architectural touch on each & \\
& elements & $\begin{array}{l}\text { component of area management } \\
\text { through providing such supporting }\end{array}$ & \\
& & $\begin{array}{l}\text { facilities as rest area, litter bin, infor- } \\
\text { mation board, and shade breezeway. }\end{array}$
\end{tabular}

Source: Setyaningsih, 2013

\section{Development Model of Kauman Tourist Village with the concept of LID toward Eco-green Tourism}

In every area development the elements of sustainability and multiplier effect are always taken into account by causing the positive impact to be greater and eliminating the negative impact which such a development may create. Resting on such a point of view, the basic concept of integrated and sustainable area development can be developed, particularly in the sustainable development of Kauman tourist village which has to be based on the dominance of local characteristics and able to fulfill the present needs without neglecting the ability of the future generation in fulfilling their future needs.

A sustainable economic condition, which is an economic activity which keeps on maintaining the basis of the natural resources used through improving knowledge, accomplishing the management of the governmental organizations and private institutions, technical efficiency, and policy determination based on mutual interest, is expected to be achieved by implementing sustainable development.

Sustainable development is essentially aimed at improving the quality of life in all aspects, inclusive of religious, physical, spiritual, and cultural aspects without wasting the natural resources at hand (particularly the natural resources with unrenewable characteristics, those without environmental and suppporting capacity. Eventually the development of Kauman tourist village considers low impact development by establishing the multifunctional development of the area into the destination of religious tourism and cultural history on the basis of eco-green tourism with the mapping on the area as follows (Figure 12): 


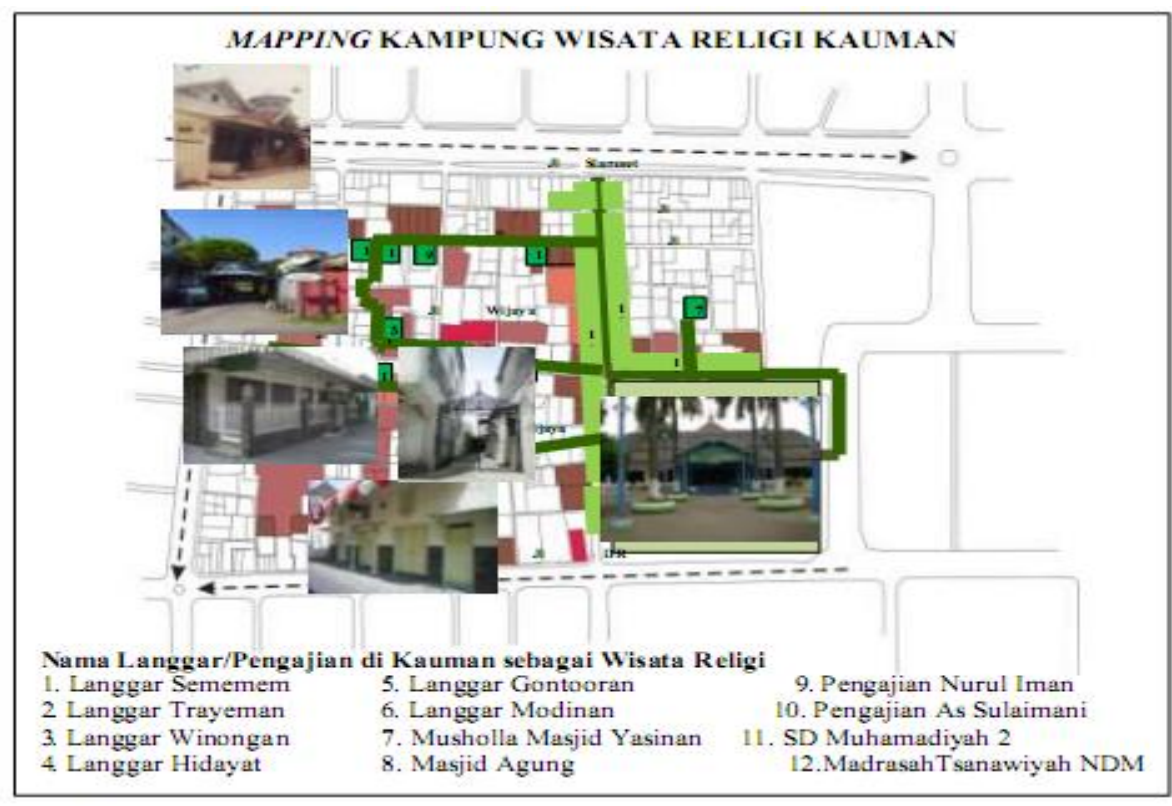

Figure 12. Mapping on the Potentials of Tourism Viewed from the Local Wisdom Potentials

Source: Setyaningsih, 2010 reanalyzed in 2013

\section{CONCLUSION}

LID has excellence in its problem-solving pattern with more environmental insight, aesthetics, and safety. Environmental management in small scale enables people to contribute more, to have low-cost environmental handling, and to implement settlement area development with low impact. The concept of settelement area development needs a particular approach in such a way that it can take more into account and maintain the condition of natural local characteristics due to the change in spatial pattern, building and environmental arrangement pattern.

The implementation of LID (Low Impact Development) strategy in maintaining and optimizing the historical area as a tourist village with the qualities of eco-green tourism, particularly in Kauman area, can be achieved through the stages as follows:

1. The identification of the dominance of potential characters as a tourist village to develop tourism sector which includes physical and non-physical aspects (building artefact, social, economic, and cultural aspects);

2. The empowerment of the non-physical potencies to raise the active role of the local people rooted in local wisdom;

3. The area space arrangement on the basis of eco-green tourism in the management of circulation track, natural resources, active motivation in the involvement of the people, and sustainable and environmentally-friendly physical development of the area of the tourist village. 


\section{REFERENCES}

Andi, S, Wiwik S, Yennel S. (2012), Review Penyusunan Master Plan Pembangunan Kebun Raya Cibinong, Jawa Baratberbasis Eco Green Environment, Laporan kegiatan Kementerian PU, Jakarta.

Anonim, (2010), Dasar-dasar Green-tourism, Kementerian Pariwisata, Jakarta.

Anonim, (2009), RTBL Baluwarti Surakarta, DTRK Surakarta.

Anonim, (2006), DISPARTA, Surakarta.

Burkart, A. J. (1982), Tourism: Past Present and Future, Second Edition, London, Heinemann.

Hermono, S. (2011), Pengendalian Aliran Permukaan Akibat Pengembangan Pemukiman dengan Konsep Low Impact Development (LID), Journal Arsitektura, ISSN 1693-3680, 09(2), Arsitektur FT UNS, Surakarta.

Inskeep, E. (1991), Tourism Planning: An Integrated And Sustainable Development Approach, New York: Van Nostrand Reinhold.

Jatmika, A., Wiwik S, Yennel S. (2011), Pengembangan Kampus Kementerian Pekerjaan Umum Berbasis Green Design, Green Infrastucture and Green Operasional \& Maintenance, Masterplan Pengembangan Kampus Kementerian Pekerjaan Umum, Jakarta.

Kemenbudpar (2007), Kriteria dan Penetapan Destinasi Pariwisata Unggulan, Kementerian Kebudayan dan Pariwisata, Jakarta.

Kostof (1991), Harmony And Hierarchy In Javanese Kampung, Asian Studies Association of Australia, Southeast Asia Publications Series No. 11 Singapura Oxford, Oxford Univ. Press, New York.

Lane, B. (1994), Sustainable Rural Tourism Strategies: A Tool For Development And Conservation, Journal of Sustainable Tourism, 2(1), 102-111.

Mcintosh, A. J. and Goeldner, (1986), .Affirming Authenticity, Consuming Cultural Heritage, Annals of Tourism Research, 26, 589-612.

Mikklesen. (2001), Metode Penelitian Partisipatoris dan Upaya-Upaya Pemberdayaan, Yayasan Obor, Jakarta.

Miles, M. B, and Huberman, A. M. (1994), Qualitative Data Analysis: an Expanded Sourcebook, Thousand Oaks, Sage.

Nuryanti, W. (2010), Local Wisdom Inspiring Global Solutions, World Conference on Culture, Education and Science, International Seminar, WISDOM 2010, UGM Yogyakarta, December 5-8th, 2010.

Nuryanti (2005), Heritage and Postmodern, Annal of Tourism Research, 32(1), Britain.

Oppermann (1996), Genius Loci: Towards a Phenomenology of Architecture, Academy Editions, London.

Setiawan, B. (2010), Kampung Kota dan Kota Kampung, Potret Tujuh Kampung di Kota Jogya, PSLH UGM, Yogyakarta.

Sharpley, J. and Sharpley, R. (1997), Rural Tourism: An Introduction, Thomson International Business Press, North Yorkshire.

Suhartanti (2000), Penataan Kampung Baru Kawasan Kedungdoro Surabaya, Unpublished paper, Universitas Brawijaya, Malang. 
Sullivan (1980), Architehture of The City, Cambridge, Mass: Massachusetts Institut of Technology Press, USA.

Setyaningsih, W. (2013), The Kauman Settlement in Surakarta and the Typology of the Rumah Ketib, Insular Diversity, Architecture-Culture-Identity in Indonesia, Published by Institute for Comparative Research in Architecture IVAICRA, Vienna, Austria.

Setyaningsih, W. (2010), Model Pengembangan Kampung Wisata melalui Peran Masyarakat dalam Pengembangan Wisata Religi dan Wisata Budaya Kauman, Dikti Research Result.

Setyaningsih, W. (2009), Model Pelestarian Kawasan Bersejarah Melalui Peningkatan Peran dan Interpretasi Masyarakat Sebagai Alternatif Pengembangan Wisata Budaya Yang Berkelanjutan, Dikti Research Result.

Setyaningsih, W. (2008), Study Evaluasi Teknik Heritage Pelestarian Kawasan Wisata Pengging, Boyolali, PMU-PU, Jakarta.

Timothy, D. J. and Boyd, S. W. (2003), Heritage Tourism, Themes in Tourism, Prentice Hall. 